\title{
Purification and catalytic properties of human caspase family members
}

\author{
Margarita Garcia-Calvo ${ }^{\star, 1}$, Erin P. Peterson ${ }^{1}$, Dita M. Rasper ${ }^{2}$, \\ John P. Vaillancourt ${ }^{2}$, Robert Zamboni ${ }^{2}$, \\ Donald W. Nicholson ${ }^{2}$ and Nancy A. Thornberry ${ }^{1}$ \\ ${ }^{1}$ Department of Enzymology, Merck Research Laboratories, R80W-250, P.0. \\ Box 2000, Rahway, New Jersey 07065, USA \\ 2 Department of Biochemistry and Molecular Biology, Merck Frosst Centre for \\ Therapeutic Research, P0 Box 1005, Pointe Claire-Dorval, Quebec, Canada \\ H9R 4P8 \\ * correspondence to Margarita Garcia-Calvo, Merck Research Laboratories, \\ R80W-250, Rahway, NJ 07065, USA. tel: 732-594-7098; \\ e-mail: margarita_garcia-calvo@merck.com
}

Received 25.8.98; revised 14.1.99; accepted 27.1.99

Edited by S.J. Martin

\begin{abstract}
Members of the caspase family of cysteine proteases are known to be key mediators of mammalian inflammation and apoptosis. To better understand the catalytic properties of these enzymes, and to facilitate the identification of selective inhibitors, we have systematically purified and biochemically characterized ten homologues of human origin (caspases 110). The method used for production of most of these enzymes involves folding of active enzymes from their constituent subunits which are expressed separately in E. coli, followed by ion exchange chromatography. In cases where it was not possible to use this method (caspase-6 and -10), the enzymes were instead expressed as soluble proteins in E. coli, and partially purified by ion exchange chromatography. Based on the optimal tetrapeptide recognition motif for each enzyme, substrates with the general structure Ac-XEXD-AMC were used to develop continuous fluorometric assays. In some cases, enzymes with virtually identical tetrapeptide specificities have $k_{c a t} / K_{m}$ values for fluorogenic substrates that differ by more than 1000 -fold. Using these assays, we have investigated the effects of a variety of environmental factors (e.g. $\mathrm{pH}, \mathrm{NaCl}, \mathrm{Ca}^{2+}$ ) on the activities of these enzymes. Some of these variables have a profound effect on the rate of catalysis, a finding that may have important biological implications.
\end{abstract}

Keywords: caspase; protease; apoptosis; inflammation

Abbreviations: ICE, interleukin-1 $\beta$ converting enzyme; IL-1 $\beta$, interleukin-1 $\beta$; IGIF, interferon- $\gamma$ inducing factor

\section{Introduction}

Members of the caspase family of cysteine proteases have been the subject of intense scrutiny in the past few years because of increasing evidence that these enzymes play major biological roles in both inflammation and apoptosis. For example, studies with mice deficient in interleukin- $1 \beta$ converting enzyme (ICE, caspase-1), the first identified member of this family, have established an essential role for this enzyme in the production of several inflammatory cytokines, including interleukin-1 $\beta$ (IL-1 $\beta)$ and interferon- $\gamma$ inducing factor (IGIF, IL-18). ${ }^{2-5}$ In contrast, caspase-3, the homologue most closely related the $C$. elegans death gene CED-3, is clearly involved in apoptosis, as is most graphically demonstrated by the phenotype of caspase-3-deficient mice, which have a profound defect in the programmed cell deaths that occur during brain development. ${ }^{6}$ Recent studies have established that, in apoptosis, caspases are involved both in upstream signalling events and in effector processes where they appear to be responsible for (i) cleavage of structural elements, (ii) inactivation of apoptosis inhibitors, and (iii) proteolytic inactivation of key homeostatic and repair processes. $^{7}$

There are eleven identified human members of the caspase family. Although the precise biological functions of many of these enzymes remain to be established, an intimate understanding of the substrate specificities of ten of them has provided some clues. All have a strict requirement for Asp in the $S_{1}$ subsite. $^{8-10}$ There is an equally stringent requirement for at least four amino acids to the left of the cleavage site. ${ }^{10}$ In contrast to the absolute conservation of $S_{1}$, there are significant differences in $S_{2}-$ $\mathrm{S}_{4}$ that dictate, at least in part, their distinct biological functions. ${ }^{1}$ Based on their extended substrate specificities, these enzymes may be divided into three major groups: Group I (WEHD), Group II (DEXD), and Group III (V,L) EXD. A comparison of these specificities with sequences found in known endogenous caspase substrates suggests that Group I caspases are involved primarily in the production of inflammatory cytokines, while Group II and Group III enzymes function as effectors and upstream activators, respectively, in apoptosis.

Two of the most distinct family members, caspase- 1 and -3 , have been purified from natural sources, sequenced, cloned and their structures determined by X-ray crystallography..$^{10-15}$ The results of these studies, together with a comparison of the primary sequences of the other caspases, indicate that all of these enzymes are synthesized as proenzymes which encode a $\mathrm{N}$-terminal domain of variable length $(2-25 \mathrm{kDa})$, a large subunit $(17-21 \mathrm{kDa})$, and a small subunit $(10-13 \mathrm{kDa})$ (Figure 1). Caspase-1 also contains a linker peptide between the large and small subunits ${ }^{10}$ and a sequence comparison between this enzyme and the other known caspases suggests that caspase-2, $-4,-5$, and -9 proenzymes may also contain a linker. For most caspases, activation appears to involve cleavage between the large and small subunits (or removal of the linker peptide), followed by release of the $\mathrm{N}$-terminal 
domain to form an active heterodimeric catalytic domain composed of one large and one small subunit. ${ }^{16,17} \mathrm{~A}$ notable exception may be caspase- 9 , where removal of the $\mathrm{N}$-terminal domain has not been observed in apoptotic cells. Both large and small subunits are excised from the proenzyme via cleavage at Asp-X bonds, suggesting that activation is either autoproteolytic, or mediated by an enzyme with a caspase-like specificity. In the crystal structures that have been determined, two heterodimers associate to form a tetramer and it has been suggested that this is the active form of the enzyme in solution. ${ }^{15}$

We have previously reported that tetrapeptides terminating in amino-methyl-coumarin (AMC) are suitable fluorogenic substrates for both caspase- 1 and $-3 .^{10,12}$ Here we describe the production and purification of ten recombinant caspases. For each enzyme, we have developed a continuous, fluorometric assay, using a substrate that contains its optimal tetrapeptide recognition motif. Biochem- ical characterization of caspases- $3,-6,-7$, and -8 has been previously described. ${ }^{18}$ In this study, we have extended this work to investigate the influence of a variety of environmental factors on the activities of ten recombinant caspases, and to define their in vitro catalytic properties.

\section{Results and discussion \\ Purification of recombinant caspases}

Several methods using a variety of expression systems have been described for the production and purification of recombinant caspases. ${ }^{19-21}$ These include expression of full length constructs under conditions where the enzyme produced is soluble, and refolding of full-length protein from inclusion bodies. The strategy employed here for the production of eight of the ten recombinant caspases involved folding of active enzyme from its constituent subunits that

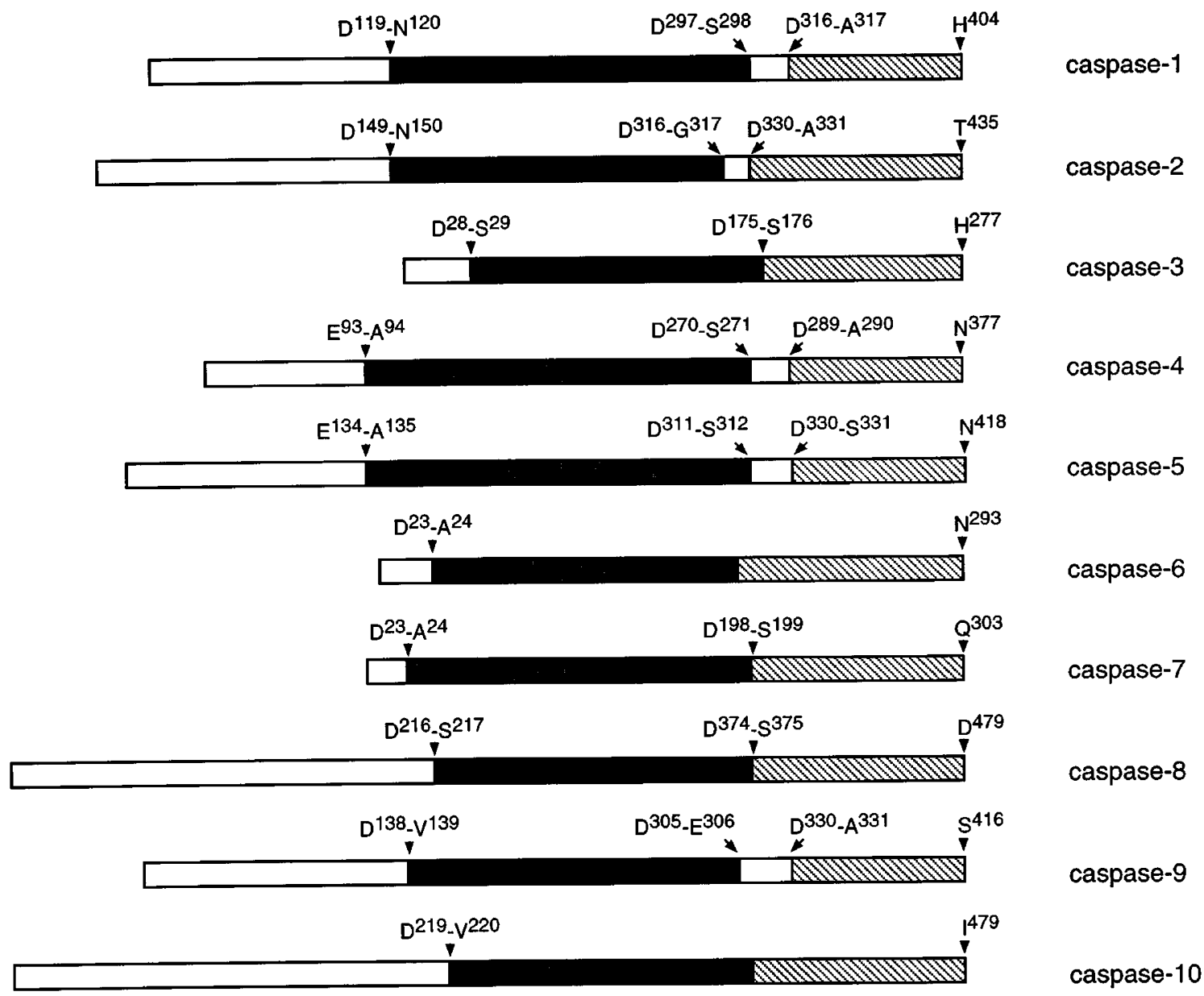

Figure 1 Caspase constructs. All caspases are synthesizes as proenzymes that encode an N-terminal domain, and a large (black) and small (grey) subunit that constitute the mature, heterodimeric enzyme. In some cases there is a linker peptide between the two subunits of the heterodimer. With the exception of caspases6 and -10 , the method employed for the production of recombinant caspases involved folding of active enzyme from the two subunits which were expressed separately in E. coli. Active caspases -6 and -10 were prepared instead by expressing a construct encoding the proenzyme minus the $\mathrm{N}$-terminal peptide. The amino acid junctions chosen for generation of the various protein subunits are indicated by the arrows. The selections of subunit boundaries were based on a comparison of the proenzyme sequences with the sequences of those caspase subunits that have been purified from natural sources (caspase-1 and -3). Consequently, it is possible that in some cases the enzyme produced using this method is not identical to that which exists in nature 
were separately expressed in E. coli, followed by ion exchange chromatography. The rationale for adopting this approach was several fold. First, as no affinity tags are incorporated to facilitate purification, the primary sequence of the enzyme produced using this method is identical to that of native enzyme. Second, studies utilizing native caspases-1 and -3 indicate that recombinant enzyme produced using this method is catalytically indistinguishable from native enzyme. Third, because the efficiency of folding is relatively high (5$20 \%$ ), conventional chromatography methods are adequate to achieve the modest purification required to obtain homogenous enzyme. Finally, the individual subunits, overexpressed and localized in inclusion bodies, can be produced in relatively high yields $(10-300 \mathrm{mg} / \mathrm{litre})$, resulting in an overall yield of active protease of approximately $1-30 \mathrm{mg} /$ litre.

The efficiency of the folding reaction was found to vary significantly with the conditions employed for a particular caspase. For example, no detectable folding of caspase-2 was observed in the presence of detergent, while Triton $\mathrm{X}$ -

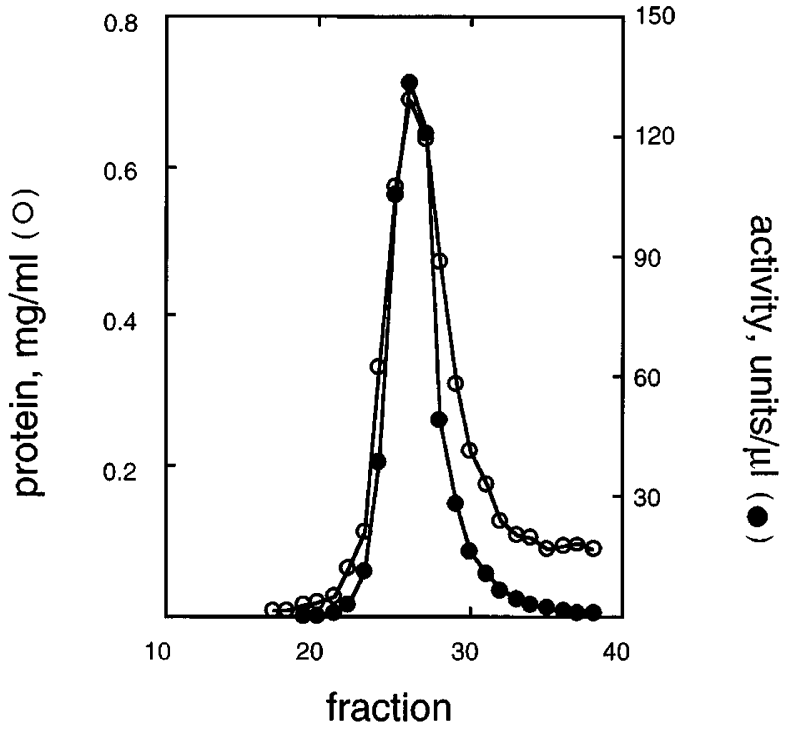

Figure 2 Ion exchange chromatography of caspase-2. Shown is a representative chromatogram for purification of active caspases by ion exchange chromatography. Caspase- 2 was folded as described in Materials and Methods, and subsequently purified to homogeneity by ion exchange chromatography. One unit of activity (closed circles) is defined as the amount of enzyme required to produce $1 \mathrm{pmol}$ of $\mathrm{AMC}$ in $1 \mathrm{~min}$ at room temperature using saturating concentrations of Ac-DEVD-AMC. Protein concentrations (open circles) were determined by the method of Bradford
$100(0.1-1 \%)$ was required for efficient folding of Group I caspases (1, 4 and 5). In addition, Group I caspases alone required the presence of a reversible inhibitor (e.g. AcYVAD-CHO) to facilitate proper folding of these enzymes. The method employed (rapid dilution) and the concentration of subunits $(100 \mu \mathrm{g} / \mathrm{ml})$ were determined to be optimal for folding of all caspases. Ion exchange chromatography was subsequently employed to separate active enzyme from improperly folded subunits. As shown in the representative chromatogram of Figure 2, a good correlation between enzymatic activity and protein concentration was observed, suggesting that purified enzyme was homogenous. This was confirmed by determining the precise molar concentration of the sample by active site titration. In all cases the value obtained was in good agreement with the protein concentration determined by the Bradford Method $^{22}$ using BSA as a standard. A typical purification is summarized in Table 1.

In the case of two caspases (6 and 10), it was not possible to use the folding method described above because of the low expression levels of their small subunits. In these cases, the enzymes were instead expressed as proenzymes lacking the $\mathrm{N}$-terminal domain, under conditions in which the expressed protein is soluble, and correctly processed. These proteins were subsequently partially purified by ion exchange chromatography.

\section{Fluorometric assays}

Previous studies have established that tetrapeptides terminating in AMC are efficiently processed by caspases- 1 and $-3 .^{10,12}$ Using a positional scanning combinatorial library with the general sequence Ac- $X-X-X$-Asp-AMC, we have determined and recently reported the optimal tetrapeptide recognition motif for caspases $1-9 .^{1} \mathrm{~A}$ similar analysis of caspase-10 indicates that the optimal recognition sequence $\left(\mathrm{P}_{4}-\mathrm{P}\right)$ for this enzyme is LEXD, where $X$ can be one of several amino acids, including threonine, serine, alanine, histidine, or norleucine (unpublished observations). This information has now been used to develop continuous fluorometric assays for all of these enzymes. In most cases, the substrate employed for a particular caspase contained its optimal tetrapeptide sequence (Table $2 A$ ). In cases where the ideal substrate was not available, a suitable substitute was selected containing a tetrapeptide that is near optimal for the enzyme of interest. Treatment of these tetrapeptide substrates with the appropriate caspase resulted in specific cleavage following the $P_{1}$ aspartic acid.

Table 1 Purification of caspase-2

\begin{tabular}{|c|c|c|c|c|c|c|c|c|}
\hline & \multicolumn{4}{|c|}{ Protein } & \multicolumn{4}{|c|}{ Activity } \\
\hline & vol, ml & $\mathrm{mg} / \mathrm{ml}$ & total $\mathrm{mg}$ & $\%$ recov. & units $/ \mu \mathbf{g}$ & total units & $\%$ recov. & $\begin{array}{c}\text { purification } \\
\text { x-fold }\end{array}$ \\
\hline Folded & 450 & 0.20 & 90 & 100 & 7.3 & $0.66 \times 10^{6}$ & 100 & 1 \\
\hline Filtered & 450 & 0.052 & 23.5 & 26 & 28.0 & $0.66 \times 10^{6}$ & 100 & 3.8 \\
\hline Applied & 45 & 0.22 & 10 & 11 & 36.0 & $0.57 \times 10^{6}$ & 86 & 4.9 \\
\hline Purified sample & 5 & 0.054 & 2.7 & 3 & 242.0 & $0.45 \times 10^{6}$ & 67.5 & 33 \\
\hline
\end{tabular}


Table 2A Kinetic constants for cleavage of fluorescent substrates

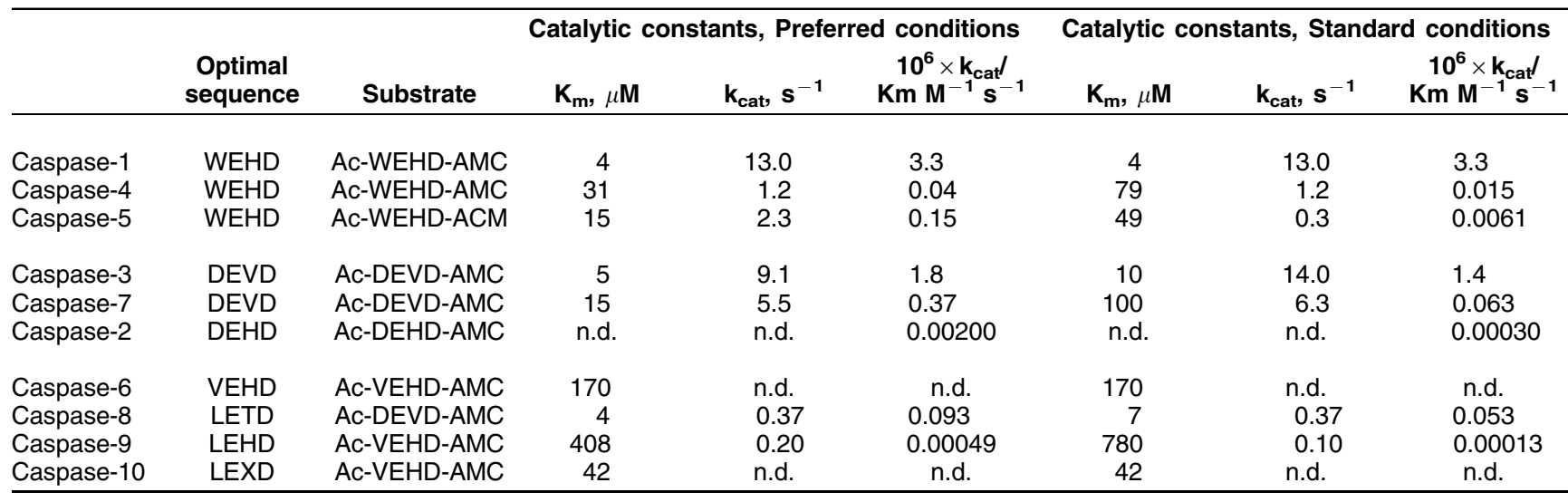

n.d. not determined. $X$ several amino acids tolerated in this position. Standard conditions: $100 \mathrm{mM}$ Hepes, 1070 sucrose, $0170 \mathrm{Chaps}$. $10 \mathrm{mM}$ ATT, pH 7.5

B Preferred reaction conditions for caspases

\begin{tabular}{|c|c|c|c|}
\hline & Buffer & Stabilizing agent & Additional reaction components \\
\hline Caspase-1 & 0.1 M HEPES, pH 7.5 & $10 \%$ sucrose & $0.1 \%$ CHAPS, 10 mM DTT \\
\hline Caspase-4 & $0.1 \mathrm{M}$ HEPES, $\mathrm{pH} 7.0$ & $10 \%$ PEG & $0.1 \%$ CHAPS, 10 mM DTT \\
\hline Caspase-5 & 0.1 M HEPES, pH 7.5 & $10 \%$ sucrose & $0.1 \%$ CHAPS, $0.2 \mathrm{M} \mathrm{NaCl}, 10 \mathrm{mM}$ DTT \\
\hline Caspase-3 & $0.1 \mathrm{M}$ HEPES, pH 7.0 & $10 \%$ PEG & 0.1\% CHAPS, 10 mM DTT \\
\hline Caspase-7 & $0.1 \mathrm{M}$ HEPES, pH 7.0 & $10 \%$ PEG & $0.1 \%$ CHAPS, $5 \mathrm{mM} \mathrm{Ca}^{2+}, 10 \mathrm{mM}$ DTT \\
\hline Caspase-2 & 0.1 M MES, pH 6.5 & $10 \%$ PEG & $0.1 \%$ CHAPS, 10 mM DTT \\
\hline Caspase- 6 & $0.1 \mathrm{M}$ HEPES, $\mathrm{pH} 7.5$ & $10 \%$ sucrose & $0.1 \%$ CHAPS, $10 \mathrm{mM}$ DTT \\
\hline Caspase-8 & $0.1 \mathrm{M}$ HEPES, pH 7.0 & $10 \%$ PEG & $0.1 \%$ CHAPS, $10 \mathrm{mM}$ DTT \\
\hline Caspase-9 & $0.1 \mathrm{M} \mathrm{MES}, \mathrm{pH} 6.5$ & $10 \%$ PEG & $0.1 \%$ CHAPS, 10 mM DTT \\
\hline Caspase-10 & $0.1 \mathrm{M}$ HEPES, pH 7.0 & $10 \%$ PEG & $0.1 \%$ CHAPS, 10 mM DTT \\
\hline
\end{tabular}

\section{Influence of $\mathrm{pH}$, salt, stabilizing agents and $\mathrm{Ca}^{2+}$ on caspase activity}

In an effort to determine the preferred assay conditions for each caspase, several reaction parameters were varied, and their influence on the catalytic activity determined. The effect of $\mathrm{pH}$ on the activity $\left(\mathrm{k}_{\mathrm{cat}} / \mathrm{K}_{\mathrm{m}}\right)$ of these enzymes is shown in Figure 3. All of the caspases exhibit a bell-shaped profile. Although this is consistent with the chemical mechanism predicted by the crystal structures of caspases- 1 and -3 , in which two ionizable groups (Cys/His) are implicated in catalysis, the finding that the apparent $\mathrm{pK}_{\mathrm{a}}$ values vary among some caspases suggests that other factors also influence the observed $\mathrm{pH}$ profiles. In most cases, the $\mathrm{pH}$ optimum is between 6.5 and 7.5. These results are generally in line with those obtained using a subset of these enzymes. ${ }^{18}$

These $\mathrm{pH}$ profiles were obtained using substrates that are optimal or near optimal for the enzyme of interest (Table 2A). Several of these contain a histidine residue that undergoes a change in protonation state over the $\mathrm{pH}$ range employed in this study, leaving open the possibility that some of the observed effects of $\mathrm{pH}$ on activity are due to ionization of this amino acid. Indeed, caspase-2, -6 and -9 were found to have $\mathrm{pH}$ optimums of $5.5-6.5,6.0-$ 6.5, and 5.5, respectively, when Ac-DEVD-AMC was instead employed as a substrate. In contrast, the $\mathrm{pH}$ profiles of caspases- $-1,-4,-5$, and -10 were not dependent on the ionization state of the substrate histidine. Whether there is any physiologic significance to the low $\mathrm{pH}$ optimums observed for some of these enzymes remains to be determined.

A preliminary survey of other reaction parameters was also conducted. Previous studies have shown that addition of viscogenic agents such as sucrose (10\%) to caspase-1 reactions significantly stabilize this enzyme, preventing its dissociation to inactive subunits. ${ }^{10}$ For this reason, the influence of sucrose $(10 \%)$ and two alternate potential stabilizing agents, polyethylene glycol (10\%) and glycerol (10\%), on caspase activities were examined. The results indicated the activity and/or stability of all caspases were shown to benefit significantly from addition of one of these reagents. For example, $10 \%$ polyethylene glycol was found to enhance the catalytic activity of caspase- 9 by approximately threefold. The influence of $\mathrm{NaCl}$ and divalent cations $\left(\mathrm{Ca}^{2+}, \mathrm{Mg}^{2+}\right)$ on catalytic activity were also investigated. Caspase- 5 was found to be the most sensitive to salt; inclusion of 
$200 \mathrm{mM} \mathrm{NaCl}$ in reactions resulted in nearly a tenfold increase in $\mathrm{k}_{\mathrm{cat}} / \mathrm{K}_{\mathrm{m}}$. Similarly, $\mathrm{Ca}^{2+}$ was found to have a significant effect (threefold) on the catalytic activity of caspase-7. The composite results of these studies led to the identification of the preferred reaction conditions for each caspase shown in Table $2 \mathrm{~B}$.
Substrate

Ac-WEHD-AMC

caspase-1

caspase-4

caspase-5

caspase-7

caspase-2

caspase-8

III

Ac-DEVD-AMC

Ac-WEHD-AMC

Ac-WEHD-AMC

Ac-DEHD-AMC

Ac-VEHD-AMC

Ac-DEVD-AMC
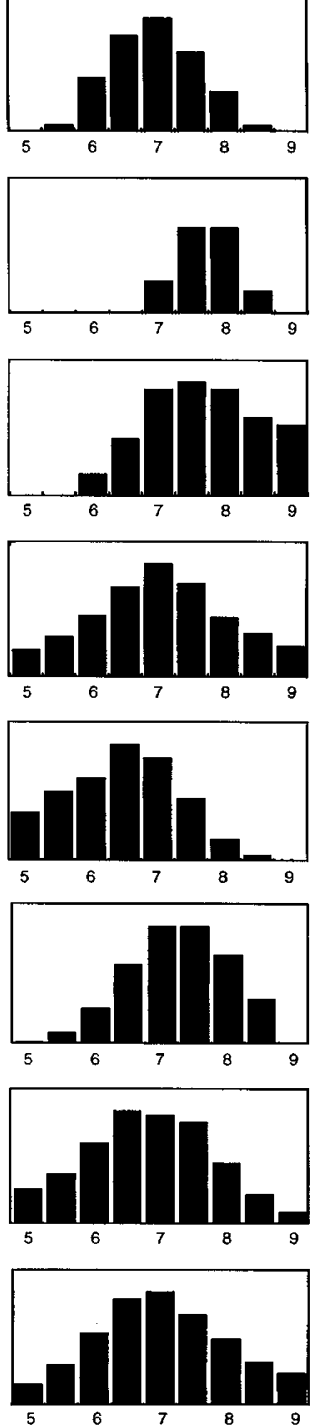

Ac-VEHD-AMC

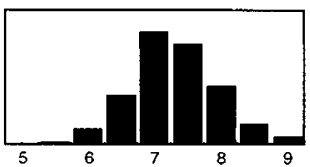

7.0

$7.5-8.0$

$7.0-8.0$

7.0

6.5

$7-7.5$

$6.5-7.5$

$6.5-7.0$

7.5

$6.5-7.5$

$6.5-7.0$

7.0

caspase-10

Ac-VEHD-AMC

Figure $3 \mathrm{pH}$ dependence of caspase activity. The activity of each enzyme was measured in a fluorogenic assay using the indicated substrate as described in Materials and Methods. The $\mathrm{pH}$ was varied over a range of 5-9 using a constant ionic strength buffer composed of $0.05 \mathrm{M}$ acetic acid, $0.05 \mathrm{M}$ MES, and $0.1 \mathrm{M}$ Tris. ${ }^{23}$ Substrate concentrations were selected such that they were below the $\mathrm{K}_{\mathrm{m}}$ determined at the enzyme's optimal pH, making it highly likely that the observed effects are due to differences in $\mathrm{k}_{\mathrm{cat}} / \mathrm{K}_{\mathrm{m}}$. The activity is shown as a percentage of the activity obtained for a given enzyme at its optimal pH 


\section{Kinetic parameters for cleavage of fluorogenic substrates}

Kinetic parameters for fluorogenic substrate hydrolysis for each caspase were measured under both standard conditions and the preferred reaction conditions determined as described above. The results, summarized in Table 2A, indicate that in some cases the efficiencies of tetrapeptide substrate hydrolysis vary dramatically, even among closely related homologues.

The two best catalysts are caspase- 1 and -3 , with $\mathrm{k}_{\text {cat }} /$ $\mathrm{K}_{\mathrm{m}}$ values of $1.75 \times 10^{6}$ and $2.1 \times 10^{6} \mathrm{M}^{-1} \mathrm{~S}^{-1}$, respectively. These values are comparable to, or greater than, the corresponding value for cleavage of known, endogenous substrates for these enzymes. For example, under similar reaction conditions, the $k_{\text {cat }} / K_{m}$ values for caspase- 1 mediated hydrolysis of pro-IL-1 $\beta$ and pro-IGIF are $1.5 \times 10^{5}$ and $1.4 \times 10^{7} \mathrm{M}^{-1} \mathrm{~s}^{-1}$, respectively. ${ }^{3,24}$ Similarly, caspase-3 cleaves PARP, DNA-PK, and U1-70K with $\mathrm{k}_{\text {cat }} / \mathrm{K}_{\mathrm{m}}$ values of 5.0, 7.7 and $2.3 \times 10^{6} \mathrm{M}^{-1} \mathrm{~s}^{-1}$.,24,25 In every case, cleavage of macromolecular substrates occurs at a site that is in accord with the known tetrapeptide specificities of these enzymes. Taken together, these observations imply that primary sequence recognition is a critical requirement for binding and catalysis by caspases, and probably the single most important determinant of the distinct macromolecular specificities of these enzymes.

Interestingly, caspases with similar, even identical, tetrapeptide substrate specificities were found to have profound differences in the rate of hydrolysis of their optimal fluorogenic substrates. For example, the substrate specificity profiles of caspase- 3 and -7 are identical, suggesting that their active sites are highly conserved. ${ }^{1}$ Nonetheless, the efficiencies of hydrolysis of their optimal substrate, Ac-DEVD-AMC, differ by approximately tenfold, even under their preferred reaction conditions. This would imply that, although the binding determinants are identical in these two enzymes, that there are subtle differences in the orientation or chemical nature of the residues involved in binding and catalysis. Similar differences in efficiency of catalysis are observed among Group I caspases (caspase $1,-4$ and -5 ), where $k_{c a t} / K_{m}$ values differ by more than $40-$ fold, despite their identical preferences for the WEHD tetrapeptide.

Two caspases are particularly poor catalysts of tetrapeptide substrate hydrolysis, caspase-2 and -9. These enzymes have $k_{\text {cat }} / K_{m}$ values for cleavage of their respective substrates that are more than 1000-fold lower than those for caspase-1 and -3. In the case of caspase-2, this observation is explained in part by the recent finding that pentapeptides are cleaved tenfold more efficiently than tetrapeptides, suggesting that this particular caspase has a slightly more extended binding pocket than do the other family members. ${ }^{26}$ However, $\mathrm{N}$-terminal residues beyond $\mathrm{P}_{5}$ did not improve catalytic efficiency, and this alone does not account for the low $\mathrm{k}_{\mathrm{cat}} / \mathrm{K}_{\mathrm{m}}$ values reported here. As for caspase-9, in apoptotic cells this enzyme appears to retain its $\mathrm{N}$-terminal domain; fully processed protein (such as that used in these experiments) has never been observed. This domain may enhance the catalytic activity of this and perhaps other caspases. As yet unknown co-factors may also be required for optimal activity of these enzymes in vivo.

In summary, we have described the systematic purification and characterization of all ten human recombinant caspases. Fluorogenic assays have been developed based on each enzyme's optimal tetrapeptide recognition motif. These assays should prove useful for further characterization of these enzymes, and will facilitate the identification of selective enzyme inhibitors. In this regard, we have found that even closely related caspases have profound differences in their catalytic efficiencies for hydrolysis of peptide substrates. This implies that these enzymes have subtle differences in their overall structures that may be exploited to produce selective inhibitors of these enzymes. The ability to identify selective inhibitors of closely related caspases may have important clinical implications, as there is increasing evidence that at least some of these enzymes have redundant functions in vivo. In particular, the phenotype of caspase-3-deficient mice suggests that, while this enzyme plays a major role in the apoptosis that occurs during the development of neurons, closely related homologues can substitute for caspase-3 function in the development of other tissues. ${ }^{6}$ Thus, in the event that inhibition of caspase-3 function will be useful for the treatment of neurogenerative disorders, selective inhibition will be required to ensure that there is no adverse effect on the apoptosis that is necessary for proper function and maintenance of other tissues.

\section{Materials and Methods}

\section{Materials}

Ac-YVAD-AMC, Ac-DEVD-AMC, and Ac-YVAD-CHO were obtained from Peptide Institute (Osaka, Japan). Ac-WEHD-AMC and Ac-VEHD$A M C$ were prepared as previously described. ${ }^{27}$

\section{Preparation of recombinant caspase-1, $-2,-3,-4,-5$, $-7,-8$ and -9}

Preparation of subunits Subunits from caspases-1,-2,-3,-4,-5,-7,-8 and -9 were engineered for expression as previously described ${ }^{1}$ (Figure 1). (The small subunit of caspase-8 was engineered for expression as the MetSer375-Asp479 small subunit. During folding and purification this subunit was autoproteolytically cleaved as Asp384-Leu385 to generate a subunit with a molecular weight of 10880.4 Da).

Exponentially growing $E$. coli BL21(DE3)pLysS carrying the respective expression plasmid were cultured in $\mathrm{M} 9$ medium at $37^{\circ} \mathrm{C}$ with overnight induction using $1 \mathrm{mM}$ IPTG for expression of the recombinant proteins. Under these conditions, the subunit protein was localized in the inclusion body fraction where it generally constituted $>90 \%$ of the total protein. The $E$. coli were harvested, washed in PBS, and broken by french press in the presence of protease inhibitors (SIGMA P 2714). Inclusion bodies were pelleted by centrifugation at $27,000 \times g$ for $15 \mathrm{~min}$. The pellets were washed four times alternating between $25 \mathrm{mM} \mathrm{HEPES} / 1 \%$ CHAPS/ $1 \mathrm{mM}$ EDTA pH=7.5 and $25 \mathrm{mM}$ HEPES/1 M Urea $p H=7.5$. Between washes the pellets were resuspended using a polytron. The inclusion bodies were solubilized 
by rotating the sample overnight in a small volume of $6.5 \mathrm{M}$ guanidine hydrochloride/25 mM Tris/5 mM EDTA/100 mM DTT pH=7.5. Following centrifugation the supernatant containing the solubilized protein was stored at $-70^{\circ} \mathrm{C}$.

\section{Folding of active caspase protein}

Each caspase was folded by rapid dilution from its corresponding denatured large and small subunits that were individually expressed in $E$. coli as described above. The subunits were rapidly diluted to a final concentration of $100 \mu \mathrm{g}$ of each subunit $/ \mathrm{ml}$ at room temperature under conditions determined to be optimal for each enzyme. The volume of the preparations varied from $20 \mathrm{ml}$ to 2 litres, depending on the quantity of enzyme desired. Caspase-1, -4 and -5 were folded in $100 \mathrm{mM}$ HEPES/10\% sucrose/0.25-1\% Triton X-100/10 mM DTT, $\mathrm{pH}=7.5$ in the presence of the peptide aldehyde inhibitor, Ac-YVAD$\mathrm{CHO}(10 \mu \mathrm{M})$. (This inhibitor can be subsequently removed following purification by treatment of the complex with hydroxylamine and glutathione disulfide as described. ${ }^{24}$ ) Caspase-2 was folded in $100 \mathrm{mM}$ HEPES/20\% sucrose/10 mM DTT, $\mathrm{pH}=7.5$. Caspase- 3 was folded in $100 \mathrm{mM}$ Tris/10\% sucrose $/ 0.1 \%$ CHAPS/150 mM NaCl/ $10 \mathrm{mM}$ DTT, pH 8.0. Caspase-7, -8 and -9 were folded in $100 \mathrm{mM}$ HEPES $/ 10 \%$ sucrose $/ 0.1 \%$ CHAPS $/ 10 \mathrm{mM} \mathrm{DTT}$, $\mathrm{pH}=7.5$. Folding was achieved by overnight incubation at room temperature. During this incubation, a substantial amount of the protein precipitates. This precipitate is removed prior to chromatography by filtration using $0.2 \mu \mathrm{m}$ pore size filters, or by centrifugation in a Sorvall RC-5 (SS34 rotor) at 15000 r.p.m. for $10 \mathrm{~min}$.

\section{Purification of recombinant caspases}

Following folding, active enzyme was separated from inactive subunit protein by ion exchange chromatography. With the exception of caspase-5, which was purified by cation exchange using a $1 \mathrm{ml} \mathrm{Hi}$ Trap SP column (Pharmacia), the enzymes were purified by anion exchange using a $1 \mathrm{ml} \mathrm{Hi}$ Trap $Q$ column (Pharmacia). Prior to chromatography, to reduce the concentration of salt, the samples were concentrated approximately 5-20-fold, followed by dilution in the appropriate buffer to achieve a final salt concentration of $<=30 \mathrm{mM}$. During this procedure, some precipitation occurs, which was subsequently removed by filtration. The standard chromatography buffer was $100 \mathrm{mM}$ HEPES ( $\mathrm{pH} 7.5$ ), 10\% sucrose, $4 \mathrm{mM}$ DTT, included $0.1 \%$ CHAPS (for caspases-3, $-7,-8$ and -9 ), and $0.1 \%$ Triton X-100 (for caspases-4 and -5). Preparations were loaded onto preequilibrated columns using a peristaltic pump at a flow rate of $0.5 \mathrm{ml} /$ $\mathrm{min}$. The columns were washed for 20 column volumes at a flow rate of $1 \mathrm{ml} / \mathrm{min}$ using a Spectra Physics HPLC, and subsequently eluted using a linear gradient from $0-500 \mathrm{mM} \mathrm{NaCl}$ in the standard chromatography buffer at a rate of $10 \mathrm{mM} / \mathrm{min}$. The purified caspases eluted from the columns between $100-300 \mathrm{mM} \mathrm{NaCl}$. Fractions (1 ml) were analyzed for activity (as described below) and protein using BSA as a standard. ${ }^{22}$ Appropriate pools were made and stored at $-70^{\circ} \mathrm{C}$. Caspase-1 was purified to homogeneity by affinity chromatography as reported previously. ${ }^{27}$

\section{Preparation of recombinant caspases- 6 and -10}

In the cases of caspase- 6 and -10 , where expression of the small subunits was problematic, active enzymes were prepared instead by expressing a construct encoding the proenzyme minus the $\mathrm{N}$ terminal peptide in $E$. coli under conditions where a portion of the protein produced is cytosolic and undergoes self-maturation.
Caspase- 6 was engineered as a MetSerPhe ${ }^{25}-\mathrm{Asn}^{293}$ prodomainless construct and caspase-10 as a MetLeuLys ${ }^{221}-11 e^{479}$ prodomainless construct. Exponentially growing $E$. coli B121(DE3)pLysS carrying the respective expression plasmid were cultured in LB medium at $25^{\circ} \mathrm{C}$ with $3 \mathrm{~h}$ incubation using $1 \mathrm{mM}$ IPTG for expression of the recombinant proteins. The E. coli were harvested, washed in PBS, and broken by french press in $25 \mathrm{mM}$ HEPES $/ 10 \%$ sucrose $/ 0.1 \%$ CHAPS $/ 4 \mathrm{mM}$ DTT $\mathrm{pH}=7.5$ in the presence of protease inhibitors (SIGMA P2714) taking care to keep the solutions on ice. The suspension was centrifuged $100000 \times g$ for $1 \mathrm{~h}$. The enzyme in the resulting supernatant was subsequently partially purified by anion-exchange chromatography (Hi Trap Q columns), as described above.

\section{Determination of caspase activity}

The activity of each enzyme was measured using continuous fluorometric assays analogous to those previously described for caspases- 1 and $-3 . .^{10,12}$ In each case a substrate with the general structure AC-XEXD-AMC was employed, incorporating a tetrapeptide sequence previously determined to be optimal for each enzyme. ${ }^{1}$ Briefly, appropriate dilutions of enzyme were added to reaction mixtures containing substrate and buffer in a total volume of $100 \mu \mathrm{l}$. Unless otherwise indicated, the buffer employed was $100 \mathrm{mM} \mathrm{HEPES}$, $10 \%$ sucrose, $0.1 \%$ CHAPS, $10 \mathrm{mM} \mathrm{DTT}, \mathrm{pH} 7.5$, henceforth referred to as standard reaction conditions. Liberation of AMC was monitored continuously at room temperature using a Tecan Fluostar 96-well plate reader (black plates from Dynatech) using an excitation wavelength of $380 \mathrm{~nm}$ and an emission wavelength of $460 \mathrm{~nm}$. Kinetic constants were computed by direct fits of the data to the Michaelis-Menton Equation using a non-linear regression program developed in this laboratory. A unit is defined as the amount of enzyme required to produce $1 \mathrm{pmole} \mathrm{AMC} / \mathrm{min}$ at room temperature using saturating substrate concentrations.

The enzyme concentrations employed for the calculations of $\mathrm{k}_{\text {cat }}$ were determined by active site titration using the inhibitor AcDEVD-CHO. In these experiments, the concentrations of enzyme and inhibitor employed were more than tenfold above the dissociation constant $\left(\mathrm{K}_{\mathrm{i}}\right)$ for Ac-DEVD-CHO and the enzyme of interest. $^{28}$ Under these conditions, the binding of inhibitor to enzyme is stoichiometric and enzyme activity is a linear function of inhibitor concentration. The total enzyme concentration was calculated as the inhibitor concentration required to achieve $100 \%$ inhibition of activity.

\section{References}

1. Thornberry NA, Rano TA, Peterson EP, Rasper DM, Timkey T, Garcia-Calvo M, Houtzager VM, Nordstrom PA, Roy S, Vaillancourt JP, Chapman KT and Nicholson DW (1997) A combinatorial approach defines specificities of members of the caspase family and granzyme B. J. Biol. Chem. 272: 17907-17911

2. Ghayur T, Banerjee S, Hugunin M, Butler D, Herzog L, Carter A, Quintal L, Sekut L, Talanian R, Paskind M, Wong W, Kamen R, Tracey D and Allen H (1997) Caspase-1 processes IFN- $\gamma$-inducing factor and regulates LPS-induced IFN- $\gamma$ production. Nature 386: 619-623

3. Gu Y, Kuida K, Tsutsui H, Ku G, Hsiao K, Fleming MA, Hayashi N, Higashino K, Okamura H, Nakanishi K, Kurimoto M, Tanimoto T, Flavell RA, Sato V, Harding MW, Livingston DJ and Su MS-S (1997) Activation of interferon- $\gamma$ inducing factor mediated by interleukin-1 $\beta$ converting enzyme. Science 275: 206-209

4. Kuida K, Lippke JA, Ku F, Harding MW, Livingston DJ, Su MS-S and Flavell RA (1995) Altered cytokine export and apoptosis in mice deficient in interleukin- $1 \beta$ converting enzyme. Science 267: 2000-2003 
5. LiP, Allen H, Banerjee S, Franklin S, Herzog L, Johnston C, McDowell J, Paskind M, Rodman L, Salfeld J, Towne E, Tracey D, Wardwell S, Wei F-Y, Wong W, Kamen $R$ and Seshadri T (1995) Mice deficient in IL-1 $\beta$-converting enzyme are defective in production of mature IL-1 $\beta$ and resistant to endotoxic shock. Cell 80 : $401-411$

6. Kuida K, Zheng TS, Na S, Kuan C, Yang D, Karasuyama H, Rakic P and Flavell RA (1996) Decreased apoptosis in the brain and premature lethality in CPP32deficient mice. Nature 384: $368-372$

7. Thornberry N and Lazebnik Y (1998) Caspases: Enemies within. Science 281: $1312-1316$

8. Howard AD, Kostura MJ, Thornberry N, Ding GJF, Limjuco G, Weidner J, Salley JP, Hogquist KA, Chaplin DD, Mumford RA, Schmidt JA and Tocci MJ (1991) IL1-converting enzyme requires aspartic acid residues for processing of the IL-1 $\beta$ precursor at two distinct sites and does not cleave $31 \mathrm{kDa}$ IL-1 $\alpha$. J. Immunol. 147: 2964-2969

9. Sleath PR, Hendrickson RC, Kronheim SR, March CJ and Black RA (1990) Substrate specificity of the protease that processes human interleukin-1 $\beta$. J. Biol. Chem. 265: 14526-14528

10. Thornberry NA, Bull HG, Calaycay JR, Chapman KT, Howard AD, Kostura MJ, Miller DK, Molineaux SM, Weidner JR, Aunins J, Elliston KO, Ayala JM, Casano FJ, Chin J, Ding GJ-F, Egger LA, Gaffney EP, Limjuco G, Palyha OC, Raju SM, Rolando AM, Salley JP, Yamin T-T, Lee TD, Shively JE, MacCoss M, Mumford RA, Schmidt JA and Tocci MJ (1992) A novel heterodimeric cysteine protease is required for interleukin-1 $\beta$ processing in monocytes. Nature 356: 768-774

11. Cerretti DP, Kozlosky CJ, Mosley B, Nelson N, Van Ness K, Greenstreet TA, March CJ, Kronheim SR, Druck T, Cannizzaro LA, Huebner K and Black RA (1992) Molecular cloning of the interleukin-1 $\beta$ converting enzyme. Science 256: $97-100$

12. Nicholson DW, Ali A, Thornberry NA, Vaillancourt JP, Ding CK, Gallant MG, Y, Griffin PR, Labelle M, Lazebnik YA, Munday NA, Raju AM, Smulson ME, Yamin TT, Yu VL and Miller DK (1995) Identification and inhibition of the ICE/CED-3 protease necessary for mammalian apoptosis. Nature 376: 37-43

13. Rotonda J, Nicholson DW, Fazil KM, Gallant M, Gareau Y, Labelle M, Peterson EP, Rasper DM, Ruel R, Vaillancourt JP, Thornberry NA and Becker JW (1996) The three-dimensional structure of apopain/CPP32, a key mediator of apoptosis. Nature Structural Biology 3: 619-625

14. WalkerNPC, Talanian RV, Brady KD, Dang LC, Bump NJ, Ferenz CR, FranklinS, Ghayur T, Hackett MC, Hammill LD, Herzog L, Hugunin M, Houy W, Mankovich $J A$, McGuiness L, Orlewicz E, Paskind M, Pratt CA, Reis P, Summani A, Terranova M, Welch JP, Xiong L, Moller A, Tracey DE, Kamen R and Wong WW (1994) Crystal structure of the cysteine protease interleukin- $1 \beta$-converting enzyme: A (p20/p10) 2 homodimer. Cell 78: 343-352

15. Wilson KP, Black JF, Thomson JA, Kim EE, Griffith JP, Navia MA, Murcko MA, Chambers SP, Aldape RA, Raybuck SA and Livingston DJ (1994) Structure and mechanism of interleukin-1 $\beta$ converting enzyme. Nature 370: 270-275
16. Han Z, Hendrickson EA, Bremner TA and Wyche JH (1997) A sequential twostep mechanism for the production of the mature p17:p12 form of caspase-3 in vitro. J. Biol. Chem. 272: 13432-13436

17. Yamin TT, Ayala JM and Miller DK (1996) Activation of the native 48-kDa precursor form of interleukin-1 converting enzyme. J. Biol. Chem. 271: 1327313282

18. Stennicke HR and Salvesen GS (1997) Biochemical Characteristics of Caspases-3, -6, -7, and -8. J. Biol. Chem. 272: 25719-25723

19. Chen W, Raybuck SA, Fulghum JR, Petrillo RA, Margolin N and Chambers SP (1997) Expression and purification of human interleukin-1 $\beta$ converting enzyme from Trichopusia ni insect cells using a baculovirus expression system. Protein Expression and Purification 9: 69-75

20. MalinowskiJJ, Grasberger BL, Trakshel G, HustonEE, Helaszek CT, Smallwood AM, Ator MA, Banks TM, Brake PG, Ciccarelli RB, Jones BN, Koehn JA, Kratz D, Lundberg N, Stams T, Rubin B, Alexander RS and Stevis PE (1995) Production, purification, and crystallization of human interleukin-1 $\beta$ converting enzyme derived from an Escherichia coliexpression systems. Protein Science 4:2149 2155

21. Sun J, Bottomley SP, Kumar S and Bird PI (1997) Recombinant caspase-3 expressed in Pichia pastoris is fully activated and kinetically indistinguishable from the native enzyme. BBRC 238: 920-924

22. Bradford M (1976) Anal. Biochem. 72: 248

23. Ellis KJ and Morrison JF (1982) Buffers of constantionic strength for studying pHdependent processes. Methods in Enzymology 87: 405-426

24. Thornberry NA (1994) Interleukin-1 $\beta$ converting enzyme. Methods in Enzymology 244: 615-631

25. Casciola-Rosen LA, Nicholson DW, Chong T, Rowan KR, Thornberry NA, Miller DK and Rosen A (1996) Apopain/CPP32 cleaves proteins that are essential for cellular repair: A fundamental principle of apoptotic death. J. Exp. Med. 183: 1957-1964

26. Talanian RV, Quinlan C, Trautz S, Hackett MC, Mankovich JA, Banach D, Ghayur T, Brady KD and Wong WW (1997) Substrate specificities of caspase family proteases. J. Biol. Chem. 272: 9677-9682

27. Rano TA, Timkey T, Peterson EP, Rotonda J, Nicholson DW, Becker JW, Chapman KT and Thornberry NA (1997) A combinatorial approach for determining protease specificities: application to interleukin- $1 \beta$ converting enzyme (ICE). Chemistry and Biology 4: 149-155

28. Garcia-Calvo M, Peterson EP, Leiting B, Ruel R, Nicholson DW and Thornberry NA (1998) Inhibition of human caspases by peptide-based and macromolecular inhibitors. J. Biol. Chem. 273: 32608-32613 